\title{
Where Would You Go? Race, Religion, and the Limits of Pastor Mental Health Care in Black and Latino Congregations
}

\author{
Daniel Bolger $1, *\left(\mathbb{D}\right.$ and Pamela J. Prickett ${ }^{2}$ \\ 1 Department of Sociology, Rice University, Houston, TX 77005, USA \\ 2 Department of Sociology, University of Amsterdam, 1012 VT Amsterdam, The Netherlands; \\ P.J.Prickett@uva.nl \\ * Correspondence: dan.bolger@rice.edu
}

check for updates

Citation: Bolger, Daniel, and Pamela J. Prickett. 2021. Where Would You Go? Race, Religion, and the Limits of Pastor Mental Health Care in Black and Latino Congregations. Religions 12: 1062. https://doi.org/10.3390/ rel12121062

Academic Editor: Kimberly Rios

Received: 20 October 2021

Accepted: 22 November 2021

Published: 30 November 2021

Publisher's Note: MDPI stays neutral with regard to jurisdictional claims in published maps and institutional affiliations.

Copyright: (c) 2021 by the authors. Licensee MDPI, Basel, Switzerland. This article is an open access article distributed under the terms and conditions of the Creative Commons Attribution (CC BY) license (https:// creativecommons.org/licenses/by/ $4.0 /)$.

\begin{abstract}
A growing body of literature explores how religious congregations shape attitudes toward mental health in racial/ethnic minority communities. Such research has primarily focused on the views of Black clergy and congregants, limiting our ability to understand how the views of Black Christians might differ from Christians in other racial/ethnic minority communities. We drew on focus groups with 14 pastors and interviews with 20 congregants from Black and Latino churches in Houston, Texas, to examine how church members make decisions about where to seek mental health care or direct others for help. We found that both Black and Latino Christians prefer seeking spiritual resources, like their pastor, when dealing with mental health issues, even though pastors feel limited in their ability to help congregants. The preferences of members of each racial/ethnic group, however, were driven by different logics. While Black Christians in this study sought spiritual resources based on perceived norms within the broader Black community, Latino Christians relied on pastoral care due to norms in their individual congregation. The results shed light on how religious beliefs, race/ethnicity, and social class intersect to shape attitudes toward mental health care in ways that have implications for potential partnerships between churches and mental health care providers.
\end{abstract}

Keywords: pastors; race/ethnicity; mental health; congregations; health care

\section{Introduction}

Recent research highlights how church-based health promotion initiatives can efficiently and effectively bridge care to historically underserved communities (Galiatsatos and Hale 2015; Levin 2014; Sattin et al. 2016). This stems from the important civic role that religious institutions play in many racial minority communities, as most Black and Latino Americans attend religious congregations (Pew Research Center 2015) but remain underserved with regards to health care (National Center for Health Statistics 2016; Ortega et al. 2015).

One health concern in which the link between race and religion is particularly salient is mental health. Indeed, a rapidly growing body of research highlights how religious beliefs help shape how congregations and their members respond to mental health concerns (Bilkins et al. 2016; Campbell and Winchester 2020; Kane and Williams 2000; Moreno and Cardemil 2013; Prickett 2021). Stigma around mental health issues and lack of access to care leave many in racial minority communities suffering from untreated health problems, especially Black and Latino Americans (Dempsey et al. 2016; Pescosolido 2013). The inability of those facing mental health challenges to find care and cope with the difficulties of everyday life can lead to feelings of "demoralization", a condition marked by hopelessness, helplessness, and a sense of failure (Costanza et al. 2020a).

Pastors act like first responders in areas where congregants hesitate to seek care. For example, African Americans are less likely than non-Hispanic Whites to believe that genetics or family of origin play a role in mental illness (Schnittker et al. 2000), which can limit their propensity to seek care from mental health professionals and helps explain why 
the pastoral role is so vital for Black religious communities (Avent et al. 2015). Recent work further suggests that pastors of Black churches feel an obligation to meet the mental health needs of congregation members (Campbell and Littleton 2018). Especially in communities with limited resources, pastors may serve not only as first responders but as the only responders on mental health (Payne 2017).

Extant research on how churches-including both pastors and congregants-approach mental health issues has largely focused on Black congregations (e.g., Avent et al. 2015; Campbell and Winchester 2020; Chatters et al. 2017; Dempsey et al. 2016; Hays 2015; Neighbors et al. 1998). Very few studies examine the views of other racial/ethnic minority groups, and even fewer utilize a comparative framework across racial groups (Nguyen 2020). The latter would enable mental health professionals to better tailor care to underserved populations, identifying where current approaches could be expanded and where new approaches need to be developed. While past research would suggest some affinities between Black and Latino Christians in their preferences for seeking out spiritual resources for mental health issues (Dempsey et al. 2016; Moreno and Cardemil 2013), we know too little about how racial/ethnic minority identities and religious beliefs intersect to shape these affinities.

The goal of the present study is to begin to unpack how race and religion might shape differences in perceptions of mental health resources and the role of clergy in providing care through two comparisons. First, we compare the perceptions of Black and Latino Christians. Second, we compare the perspectives of pastors and congregants. To do so, we ask the following question: how do Black and Latino Christian pastors and congregants perceive mental health concerns within their congregations and how do these perceptions influence their decisions about where to seek mental health care or direct others for help? Drawing on focus groups with 14 pastors and semi-structured interviews with 20 congregants at Black and Latino churches in Houston, Texas, we find that in all studied churches, mental health concerns were perceived as ubiquitous. In part because of their frequency in dealing with such concerns, clergy felt ill-equipped to provide adequate care. At the same time, we find discursive differences in the ways that members of each racial/ethnic group spoke about stigmas surrounding mental health issues and their implications for help-seeking. The results further underscore the importance of the pastoral role for identifying and addressing mental health issues for underserved communities, but also highlight how initiatives must be tailored to different populations based on prevailing norms around mental health within congregations and the broader racial/ethnic communities in which they are embedded.

\section{Mental Health and the Black Community}

There have been no shortage of empirical studies exploring the socio-historical role of churches within Black communities in the U.S. (e.g., Lincoln and Mamiya 1990; PattilloMcCoy 1998; Baumann 2016). As one of the few institutions in the U.S. controlled by Black Americans, churches have long been sites of community activism (Cavendish 2000), social service provision (Barnes 2004), and health promotion (Gross et al. 2018). Recent studies, for example, argue that Black churches are uniquely well-positioned to provide mental health care to Black Americans because of the trust they engender within predominantly Black communities (Campbell and Winchester 2020; Hays 2015).

Numerous studies over the past ten years have focused on how churches might socialize Black Americans into particular ways of thinking about mental health, thus shaping the ways that clergy provide care and members seek help. First, Black pastors are often first responders to mental health issues and spend more time than clergy from other racial ethnic groups offering pastoral counseling to older adults (Neighbors et al. 1998; Pickard et al. 2019). Indeed, churches in predominantly Black communities are more likely to offer mental health programming than churches in communities populated primarily by other racial/ethnic groups (Wong et al. 2018). Second, and relatedly, Black pastors can be reticent to partner with or refer congregants to mental health professionals 
(Dempsey et al. 2016). This is not only because Black pastors are more likely than White clergy members to see mental health issues as a result of spiritual failures or tribulations (Payne 2009), but it also might relate to distrust of medical professionals in many Black communities (Hankerson and Weissman 2012). Finally, Black pastors are unlikely to seek out mental health professionals for themselves; church leaders who attend services more frequently, for example, are less likely to seek outside mental health care (Bilkins et al. 2016; Okunrounmu et al. 2016).

Research on perceptions of mental health care among Black Christians highlights similar themes. For one, research finds that Black congregants tend to seek mental health care from informal sources, like clergy members, friends, or family. This is true even for Black Christians who report lower levels of religious commitment (Hays and Lincoln 2017). However, reliance on church leaders for mental health care may reduce the likelihood of seeking later professional care. Earlier research on this topic suggested that those who first sought a pastor for a mental health concern were less likely to seek subsequent professional guidance than those who sought different sources of initial help (Neighbors et al. 1998). Similarly, like pastors, Black Christians often see mental health concerns as connected to spiritual health (Holt and McClure 2006).

Initial research on views of mental health in Latino churches, though limited, finds similar patterns. Like Black churches, Latino congregations are often seen as important sites for mental health interventions, because of the trusted role that such churches play in many Latino communities (Caplan 2019). Research also suggests that many Latino Christians prefer seeking help from religious leaders when facing mental health issues (Kane and Williams 2000). Further, Latinos who would seek out mental health professionals prefer those with congruent religious values (Moreno and Cardemil 2013). Research also suggests that Latino Christians often perceive mental health concerns as resulting from spiritual factors. Caplan (2019), for example, finds that Latinos in faith-based settings often attribute mental health issues to factors such as demonic forces, sinful behavior, or a lack of religious faith. As such, respondents saw spiritual practices such as prayer and reliance on God as necessary to protect individuals from both health and mental health issues (Jurkowski et al. 2010). Finally, studies suggest that mental health can be highly stigmatized among Latino Americans. This stigma is one reason Latinos might seek pastoral care or other spiritual resources for mental health care. For example, in one study of Latino Americans struggling with mental health concerns, only one-third of respondents reported seeking professional help (Villatoro et al. 2014). Caplan (2019) attributes stigma partly to socialization around mental illness in Latino religious congregations, suggesting that many Latino Christians are taught to see mentally ill individuals as incurable or even dangerous.

Thus, past research suggests there might be many similarities between Black and Latino Christians in how they view mental health care. Members of both groups often utilize spiritual resources for mental health concerns, view mental health issues as resulting from spiritual factors, and can avoid seeking help due to stigma around mental health (Hays and Lincoln 2017; Moreno and Cardemil 2013). None of the aforementioned studies, however, directly compare the two groups. Rather, most focus on a single racial/ethnic group. When a comparative design is employed, Whites often serve as the reference group (e.g., Chatters et al. 2017; Kane and Williams 2000; Payne 2009). The limited number of studies that do compare Black and Latino Americans focus largely on how religious practices shape mental health outcomes (Sternthal et al. 2012; Villatoro et al. 2018).

In the present qualitative study, we adopt a comparative framework to explore how Black and Latino Christians make decisions about where to seek mental health care, the logic driving such decisions, and the role of pastors in that process. We find that these two racial/ethnic groups share an affinity for seeking spiritual resources when confronted with a mental health issue but articulate different logics for doing so, demonstrating how race, religion, and social class intersect to help shape perceptions of mental health. Far from inconsequential, these differences have important implications for developing targeted 
interventions to assist pastors working on the frontlines of mental health care in historically underserved communities.

\section{Materials and Methods}

The data come from a larger project examining how racial minority Christian congregations in Houston, Texas, view the interface between faith, science, and medicine. This study focuses on two racial/ethnic groups: Black and Latino Americans. Both groups are highly religious - with particularly high representation in Christian traditions-but underrepresented in scientific and medical careers (Association of American Medical Colleges 2014; National Science Foundation 2013). Past research suggests that representation in health care professions might shape levels of medical distrust among racial minority groups (Kennedy et al. 2007). Data for this study were collected in 2015-2016 and included focus groups with fourteen Black and Latino pastors and 20 interviews with church members across two congregations.

\subsection{Focus Groups}

Pastors from both racial/ethnic groups were identified and invited to participate in one of three focus groups. Researchers identified local pastors through online resources, recommendations of faith leaders, and connections of the research team. A total of 28 pastors of Black and Latino churches were invited to participate; 14 took part in one of the three focus groups. All groups were conducted in September 2015 and each lasted for approximately $1.5 \mathrm{~h}$. Researchers collected basic demographic information, including the pastor's age, education level, and race. The rationale for utilizing focus groups was twofold: such an approach would help generate themes for further investigation while also allowing pastors from each racial/ethnic group to collectively shape the conversation from the perspective of their own faith communities. Focus groups-because of the interactions they foster-often produce different themes than interviews even if similar questions are asked of respondents (Carter et al. 2014). This is one reason why focus groups are often utilized in health research, where researchers are interested in uncovering previously unseen obstacles to intervention.

Four Black pastors participated in the first focus group, four Latino pastors participated in the second group, and the final focus group was conducted with six Black pastors. Three of the clergy members were women, each of whom worked at a predominantly Black congregation. Most pastors were the senior (or only) clergy member at their congregation, although two were associate pastors.

\subsection{Observations and Interviews}

Upon completion of the focus groups, one congregation from each racial/ethnic group was selected for deeper study. While the selection process was guided in part by practical concerns (i.e., churches that agreed to be part of the study), we attempted to select typical cases, or congregations that typified the traditions they represented. For example, estimates suggest that 45 percent of all Black Americans in the U.S. identify as Baptist (Pew Research Center 2015) and 64 percent of Latino Protestants identify as Pentecostal (Espinosa 2014). The two churches in the present study therefore serve as "paradigmatic" cases in that they represent denominations commonly attended by Black and Latino Christians, thus helping us to identify dynamics and perceptions that might exist in similar congregations (Flyvbjerg 2006). The Black American congregation selected for the study was a Baptist church, with a weekly attendance of approximately 600 members. The Latino congregation, a Pentecostal church, had about 70 weekly attendees.

Researchers identified interview respondents through participant observation in both congregations and by soliciting recommendations from church leaders. Observations included attending worship services, Sunday school classes, and other church programs. All observations were conducted during fall 2015. In total, the research team interviewed 20 church members across the two congregations. Ten interviews were conducted with 
members of both the Black congregation and the Latino congregation. Half of the interview respondents had completed a Bachelor's degree. Almost two-thirds (63 percent) of the respondents were women. The ages of respondents ranged from 24 to 65 .

\subsection{Data Analysis}

We utilized a semi-structured interview guide for both focus groups and interviews. Here we focus primarily on one question: "Where would you go if you had a mental health concern?" We utilized an abductive approach to data analysis (Tavory and Timmermans 2014), which aims to find "surprises" by comparing data to existing literatures in an explicit attempt to cultivate novel findings. Indeed, the topic of mental health was not part of our original focus group interview guide but arose unsolicited among pastors in all three groups. Their lack of perceived confidence to address mental health issues stood out as a source of possible tension when considered in light of the literature on religion and mental health. We then asked congregants about where they would go if they had a mental health concern, enabling us to uncover differences in the perceived abilities and limits of pastor mental health care. Throughout the analysis, we focused on identifying similarities and differences across racial/ethnic groups in how church members described where they would go for help with their mental health and the decision-making process through which they explained such preferences.

\section{Results}

\subsection{Congregants' Mental Health Resource-Seeking}

When asked what they would do if faced with a mental health concern, many Black and Latino Christians reported that they would either pray or seek their pastor. In fact, "pastor" was the mostly commonly cited mental health resource mentioned across our sample; some even mentioned that their pastor was the only person they would seek. For many, the decision to consult their pastor seemed self-evident, and they described the pastor as uniquely qualified to deal with mental health issues. One member ${ }^{1}$ of the Black church, in speaking about how she would help a friend experiencing mental health issues, told us: "I wouldn't send them to a psychiatrist, I would recommend them talk to the pastor first ... . pastors for some reason can draw more out of people than a regular person, just because they have that title". The respondent later explained that pastors have "the gift of discernment" and that "whatever he says, it goes". Her trust in the pastor as a mental health care provider was so complete that she would dissuade a friend from seeking help from a medical professional. Even Black congregants who reported that they had visited counselors or psychiatrists in the past suggested that their pastor would be the first point of contact if a future issue arose. "I would bring it to the pastor first. Yeah, the pastor", one woman ${ }^{2}$ explained, "it could be life or death, so he's the first point". Notice how if it is a life-or-death situation, the pastor is the obvious point of contact, with "so" used as a conjunction to indicate a next step. This suggests the pastor's authority carries special meaning, likely owing to religion's existential importance.

The responses of Latino congregants were similar. Most said that they would pray or seek out their pastor if facing a mental health issue, although respondents in this population tended to express more recognition that the pastor may not be the only resource they would seek. And some preferred to keep mental health concerns to themselves, including one congregant who said, "I would try to be strong and address it myself with God and be like 'God why you hatin' [laughs]". The same respondent later acknowledged that they would seek the pastor's counsel if communication with God did not lead to a desired change: "I think he [the pastor] plays a very important role altogether in anybody's life". Congregants often recognized that this "very important role" might also involve the pastor referring them to another health care provider. As another member ${ }^{4}$ of the Latino church explained, "[t]he first person I'd go to would be my pastor, and if there's anything-if he needs to refer me to anybody then (he could)". While very few congregants in the Latino congregation reported that they would seek help from a mental health professional or 
doctor if confronted with a mental health issue, many suggested that they would be open to such help only if referred by their pastor.

In many cases, regardless of race/ethnicity, preferences about where to seek help or refer other congregants were not hypothetical. Members of both churches perceived mental health issues to be pervasive within their congregations as well as society at large. "I mean everybody suffers from depression, I think almost 80 percent of the world", one Latino congregant $^{5}$ told us. This shaped how congregants and lay leaders responded to some Sunday morning visitors deemed as potentially unwell. A Black congregant ${ }^{6}$ said, "I'll see an individual from like off the streets walk through the door and knew that they had a mental health issue, and they'd have to be escorted out". The respondent, a nurse, made clear she was "[n]ot trying to be mean but just have to escort him out, because we don't know what they're liable to do".

Other congregants admitted struggling with mental health issues themselves, though they tended to frame the problem as one that occurred in the past (likely due to the aforementioned stigma present in many Black and Latino communities). One Latino man ${ }^{7}$ told us, "[G]rowing up, you know, the way I grew up, I was feeling kind of suicidal and I used to sometimes cut myself". A woman from the Black congregation described herself as "an attempted suicide survivor", before lamenting the fact that people "just didn't talk about suicide" in the Catholic church in which she grew up. Thus, congregants perceived mental health issues to be pervasive within both their church and in the broader community. Church members felt uncertain about how to help others and where to go with their own needs, often making the pastor the default option when any concerns arose.

\subsection{Pastors' Feelings of Limitation}

Like their congregants, pastors told us they saw mental health as both pervasive and a major source of suffering for congregants. One Latino pastor ${ }^{8}$ said:

I think about 80 percent of the people that come into our church are suffering from depression. They deal with a lot. And about eight years ago we did a survey of people in our church. Fifty percent of adults had experienced sexual molestation. I was astounded.

We were struck time and time again by how overwhelmed pastors felt as a result of the mental health needs of congregations. In our first focus group with Black pastors, before we had even asked about mental health, the topic generated a conversation in which pastors actively tried to solicit help from each other to know how to better deal with mental health concerns in their individual congregations. For example, one pastor told the group he was looking for someone to help provide care for children with autism in his congregation, leading another to inform him of a special needs ministry recently started at her church:

It's a mental health deal but then we also just launched-literally in the last two weeks, it was just announced that a special needs ministry would be launched at the church. So, there's one part is for mental health issues similar to that.

This suggests that pastors are eager for help, an idea we pick up in the conclusion when discussing the practical and policy implications of this study.

Several pastors tried to address mental health issues among the congregation as a whole but they also noted that their congregants were ambivalent about how best to address mental health in the church. One Black pastor" said, "[W]hether they are the working class, the poor class, or upper-middle class ... I talk about mental health and mental awareness and (congregants are) more tolerant than excited about the information". This pastor said that his congregants felt they had more pressing demands than health. One pastor paraphrased a common response in his congregation as: "Pastor, you bringing in people to talk about healthy lifestyle, healthy living, but can you tell me how to budget my household with the income I currently have?" Past research highlights how subjective financial hardship is associated with depression (Mirowsky and Ross 2001) and suicidal ideation (Frankham et al. 2020); as such, the concerns of congregants were not necessarily 
disconnected from mental health concerns. However, this was not a link that congregants (or pastors) explicitly made.

Perhaps because of the perceived scope of the problem as well as their congregants' tendency to want to consult their pastors on mental health issues, pastors expressed feeling overwhelmed. Many said they were ill-equipped to handle such issues. One Black pastor ${ }^{10}$ explained: "I'm a pastor, I can tell you about Jesus. I can dig into scriptures; I can read that. But you have some psychological issues I'm not prepared to help you walk through". In other words, what made the pastor uniquely qualified in the eyes of congregants was in fact a limitation from the perspective of the pastors themselves. One Latino pastor ${ }^{11}$ of a small Pentecostal church noted that "even though we're like a high faith church, we have to kind of be open to everything because sometimes I can pray for somebody and it's gone. Other ones it doesn't matter how much Bible studies and teaching we do, they still struggle". A Black pastor ${ }^{12}$ articulated similar concerns in highlighting the importance of pastors recognizing the limits of their competence. He argued that clergy members cannot be afraid to say "this is beyond my scope. I need to refer you to someone else who can lead you in these particular ways".

At the same time, several pastors expressed doubt about the abilities of medical and mental health professionals to provide comprehensive care for congregants. As one pastor $^{13}$ explained, "[T]here are things that the clinical psychology and all of-psychiatry that feel they can deal with some things but they may not be skilled to handle the spiritual matters". She then explained that pastors can handle matters that medical professionals cannot. Another Black pastor ${ }^{14}$ added, "[W]e're aware that medicine can go only as far as knowledge and there are some things beyond test tube knowledge". Thus-even for pastors-there was a tension in balancing the respective roles of religion and medicine in addressing mental health concerns.

Often perceptions of the potential of medical professionals to serve church members were tied to the socioeconomic composition of the congregations itself. Pastors of churches in middle- or high-SES communities, for example, were often more optimistic about the potential efficacy of medical care for congregants struggling with mental health issues, often because many of their congregants worked in medicine. As one pastor ${ }^{15}$ from a middle-class community explained,

God has blessed (church name) with a large percentage of our membership is in the medical field. So either I'm-if they want to keep things confidential I would ask the people who are in the medical field, who would you recommend that I would send this person to for help beyond my scope?

As the preceding narratives suggest, not all Black pastors viewed medical and mental health care professionals with skepticism. Their perceptions were shaped-at least in partby the representation of medical professionals in the congregation itself. Past research has highlighted similar differences across SES groups among Black Protestants, particularly in their views of the potential bias of scientists (Tinsley et al. 2018).

Congregants also acknowledged feelings of limitation in their ability to provide support to other people in their churches who they thought might be struggling from mental disorders, highlighting the limitations of social support in these spaces. One 61-year-old African American congregant-herself a healthcare worker-said, "I've got a sister right now, she was assigned to me several years ago, and she was described as schizophrenia [sic] ... But the church has been challenged as how to help her. I mean, you pray, you give her suggestions, you try to help her identify resources in the community, but you feel limited, I feel limited". A member ${ }^{16}$ of the Latino church described a similar situation in which he struggled to help someone who approached him and reported grappling with mental illness. "I couldn't think of anything", the member explained with a sense of frustration, "All I did was, I gave her a hug [laughs], and I just listened. I thought that she wanted me to listen. That's all I gave her, but other than that, I was stuck". Words like "challenged" and "stuck" suggest congregants experience negative feelings in 
interacting with other congregants facing mental health challenges. Thus, far from feeling empowered to create a space where mental health issues could be fruitfully addressed, both pastors and congregants articulated feelings of inadequacy.

\subsection{Mental Health, Race, and Religion}

Consistent with the expectations of prior scholarship, Black and Latino Christians in our study reported a high propensity to seek out spiritual resources-particularly their pastor-when facing mental health issues. But they also voiced feelings of limitation in their ability to care for and counsel congregation members struggling with mental health issues based on the perceived ubiquity of such concerns within their religious communities. Congregants felt uncertain; pastors felt overwhelmed. Despite these affinities, however, there were notable discursive differences in the ways that members from each racial/ethnic group explained "why" mental health issues were pervasive, stigmatized, and difficult to address within congregations themselves. These discursive differences provide a glimpse of how religion, race, and class intersect to help shape perceptions of mental health care.

For our Black congregants, responses to mental health crises were deeply informed by explicit notions of race and perceived social norms within the broader racial/ethnic community. Thus, the "Black community", rather than religious beliefs or even the "Black church", served as the reference point through which congregants and pastors explained their help-seeking preferences with regards to mental health. The wife ${ }^{17}$ of the pastor at the Black congregation we studied put it this way: "Okay so here's the thing with African Americans: If you have mental health issues, you don't go to anybody, and most people who do probably will go to-will come to talk to my husband the pastor". What is notable about the congregant's statement is not the fact that she believes that most people would come see her husband if in need of mental health care, but the lack of religious reasoning to frame this expectation. She traces the unwillingness of congregants to seek mental health care to communal norms among African Americans. In particular, she hints at the stigma of mental illness, which can lead people to not "go to anybody". As such, stigma surrounding mental health was seen as functioning well beyond the walls of the church.

Other congregants highlighted the stigma surrounding mental health issues among Black Americans in more explicit terms. "[E]specially in the Black community, we were taught what happens at home stays at home, right?" one Black woman ${ }^{18}$ explained, before going on to say, "it's a huge stigma". Again, it was notable that this stigma was seen as a broader communal norm rather than something unique to religious congregations (for a similar absence of religion in framings of mental health, see Prickett 2021). Other respondents made similar statements linking stigma and the broader racial community. As one congregant ${ }^{19}$ explained, "for the Black community, they don't go to doctors, but I'm pretty sure they go to their pastors about it".

While recognizing the heterogeneity that exists among Black Americans, congregants in our study articulated a relatively clear sense of norms beyond their individual congregations and the potential implications of those norms for individuals facing mental health challenges. As one Black congregant ${ }^{20}$ explained, "mental health, you know ... some of the things we have problems (with) we don't address and in our culture for some reason, we discount counseling, we don't want counseling, so we go to [the] grave with anything". Consistent with past research, the respondent suggests that Black Americans are often skeptical about counseling. But the propensity to "go to the grave with anything" is not identified as religiously motivated; rather, it is perceived as a community norm.

Latino congregants in this study framed their propensity to seek pastors in different terms. For Latino Christians, seeking the pastor was articulated as a product of religious beliefs - particularly perceptions of the spiritual etiology of mental illness—and church norms within their religious community, rather than the broader racial/ethnic community. One Latina church member ${ }^{21}$ explained: "I know there are other resources, whether a lot of people are aware of those or you know, maybe too ashamed to go to that first, I think ... if you're a long-term member of the church I believe they would talk to the pastor first". 
Similar to responses from Black respondents, this congregant assumes that other members of her church would talk to their pastor first if confronted with a mental health issue. Yet, this propensity is framed as a result of long-term church membership. Explained another congregant, 22 "I think everybody in our congregation [emphasis added] would pray about it first. But I do believe most of them would turn to pastor". As the quotes epitomize, Latino congregants were less likely to speculate on how individuals outside of their congregation might respond to mental health concerns, and they rarely referred to "Latinos" as a whole.

As with help-seeking preferences, perceived stigma around mental health issues among Latino congregants was also directly tied to the norms and beliefs of Christian churches. "Counseling's always been that, there's a stigma, like you need to be ... talking to your pastor", explained one Latino congregant, 23 "but then after that, you need to talk to God, because that's something that you need to deal with". As the same congregant went on to explain, the stigma of mental health sometimes related to beliefs about the spiritual etiology of mental health problems. "Stigma is that you're crazy ... you'll get labeled as that, that you're just crazy or even-some people view it that some spirits that are on you that are kind of controlling your mind and that maybe you don't have a strong walk with God", he noted. Again, the congregant highlights the ways that stigma surrounding mental health is spiritual in nature, and thus solutions were driven by religious motivations to demonstrate a "strong walk with God".

Whereas in the Black congregation respondents were hesitant to frame mental health problems in religious terms, members of the Latino congregation we interviewed were more likely to explain mental health issues as related to sin or lack of commitment to God. This included references to serious mental illness. One worship service at the Latino congregation, for example, began with a band leading church members in worship as many congregants danced, lifted their hands, and prayed out loud. As the music faded, the co-pastor came on stage to give a series of prayers and admonitions. Lifting his voice to match the fervor of the gathered worshipers, he said, "if you have the Spirit you will not be depressed"! ${ }^{24}$ Such pronouncements were often followed by the pastor encouraging members to share their "testimonies", or ways that they had been delivered from sin or had a prayer request answered. On one occasion, a woman stood up and shared her concerns about a "bipolar" neighbor whose affliction had been lifted through prayer. ${ }^{25}$ Such examples highlight how mental health terms were utilized within the context of services, but also how they were often connected directly to sin and the spiritual health of members.

Indeed, some Latino respondents extended this line of logic to suggest that mental health only becomes a topic of conversation in churches like their own when congregants could claim that they have been healed or relieved of their affliction. As such, mental health issues were only talked about in the past tense; recovery was valorized as a spiritual triumph over sin worth sharing with the religious community. When discussing the conditions under which a congregant would seek out help for mental health care, for example, the pastor's wife ${ }^{26}$ at the Latino congregation explained, "I think maybe just with the pastor or somebody that they really have trust in but not openly unless they can say, 'God cured me.'" Thus, discussions of mental health issues were not completely ignored within the context of congregational life; rather, they were used to highlight the efficacy of spiritual resources for addressing such issues.

Even when biological explanations were invoked for mental health, congregants still saw spiritual resources as the best (and most accessible) solution. For example, when talking about the possible etiologies of mental health issues, one Latina congregant explained, "[m]aybe an issue comes up because, say for example, a woman is going into menopause. So ... her hormonal balance is going down, so it affects her mentally, she's depressed". She then went on to say, "[b]ut what do we do? The very first thing that we do-come up let's get some oil and let's pray for you" ${ }^{27}$ Consistent with their identity as a Pentecostal church, members of the Latino congregation placed an emphasis not only on prayer but also in celebrating when prayers were efficacious. 


\section{Discussion}

Churches have long played an important and multifaceted role in communities of color in the U.S. (Baumann 2016; Gross et al. 2018; Lincoln and Mamiya 1990). Recent work has focused more specifically on how such congregations approach addressing issues of mental health, highlighting how pastors often serve as first responders but also face distinct challenges given the prevalence of mental health concerns both within and beyond their congregations (Campbell and Winchester 2020; Hays 2015). Utilizing a comparative framework, we find affinities between Black and Latino Christians in the ways they approach mental health care, but different logics for making decisions of where to seek help. Black congregants often cited stigma and norms in the broader racial/ethnic community; Latino congregants often cited perceptions of the spiritual etiology of mental health issues and help-seeking norms within the religious community. These results have implications for understanding heterogeneity across racial/ethnic minority congregations while also suggesting that initiatives oriented toward promoting mental health care via churches need to be tailored to meet the needs of particular congregations based on extant norms around help-seeking.

Echoing past scholarship, our results highlight the importance of the pastor in many racial/minority congregations (Avent et al. 2015; Campbell and Littleton 2018; Payne 2017). Public health initiatives, particularly those oriented toward mental health promotion, certainly cannot ignore this reality. While the norms that dictate seeking out the pastor might differ across religious and racial/ethnic communities, in both of our cases the pastor was seen as having a special "pull" that enabled them to best craft a plan of care for individuals facing mental health challenges. Religion not only provides what psychologists call "meaning in life", but seeking out pastoral help in times of suffering and crisis might also be a means by which people search for such meaning (Costanza et al. 2020b). This hints at the existential importance of religion in racial/ethnic minority communities, where a preference for spiritual resources for addressing mental health issues might connect also to processes of meaning-making in the wake of suffering.

Past research suggests that seeking out the pastor first can be consequential for whether congregants later seek care from a mental health professional. For example, one study found that only 30 percent of congregants who seek their pastor first for mental health care then seek other resources, compared to 46 percent who seek another resource first (Neighbors et al. 1998). Congregants in our study were not opposed to seeking a mental health care professional but would often do so only if referred by their pastor. Importantly, we found that pastors often did not feel equipped for the scope of the role their congregants desired when it came to addressing mental health. Pastors may see themselves as obligated to help congregants in these concerns (Campbell and Littleton 2018), but if they are overwhelmed doing so, then their effectiveness may be limited.

Ultimately, our results cannot disentangle the respective influences of race, theology, and social class in shaping perceptions of mental health care and help-seeking. Our findings do, however, suggest that these factors intersect in ways that must be considered by mental health professionals. While members of the Black Baptist Church and Latino Pentecostal Church in our study shared an affinity for seeking spiritual resources, they utilized different logics in framing their decisions. Black congregants often explained their preferences based on perceived norms in the broader racial/ethnic community, rather than their individual theological beliefs or norms in their particular congregation. This finding provides one potential explanation for past research suggesting that Black Christians are likely to seek informal services for mental health care regardless of their levels of religious involvement in a congregation (Hays and Lincoln 2017). If seeking the pastor for mental health care is perceived to be a communal rather than religious norm, it is likely that Black pastors might be sought out by individuals well beyond the walls of their congregations (see also Davenport and McClintock 2021).

Conversely, when discussing how they would seek mental health care for themselves or others, Latino congregants appealed more to the norms of their individual congregation 
and the perceived spiritual etiology of mental health issues. The latter finding echoes past scholarship suggesting that Latinos often attribute mental health concerns to spiritual factors (Caplan 2019; Jurkowski et al. 2010), a belief that might be particularly salient in Pentecostal churches. But Latino congregants and pastors did not simply frame their views on mental health resources in theological terms; they suggested that congregants would seek the pastor first because of the perceived norms of their local religious community. Indeed, despite acknowledging the stigma surrounding mental health in many churches, members of the Latino congregation in our study often spoke about mental health challenges during services, albeit in past tense, thus raising awareness of the prevalence of mental health concerns within their congregation. One potential explanation for the differences across racial/ethnic groups in the study might relate to perceptions of racial/ethnic identity. Given the heterogeneity in racial identification that exists among U.S. Latinos (Golash-Boza and Darity 2008), Latino Christians like those in our study might be less likely than Black Christians to see themselves as part of a larger, pan-ethnic "Latino community" (Okamoto and Mora 2014). Indeed, our Latino respondents rarely referred to a broader racial/ethnic community that might shape norms around mental health care.

The present study is not without limitations, each of which provides direction for future research on the relationships among religion, race, and mental health. First, while our study was novel in comparing Christians across racial/ethnic groups, the primary churches in our study came from different denominations and theological traditions. This limits our ability to disentangle how the respective racial compositions and theological traditions of each congregation shape perceptions of mental health. For example, past research suggests that pastors of Pentecostal congregations are more likely to see mental health concerns as having a spiritual or moral etiology (e.g., Payne 2009), and thus it would be unsurprising that Pentecostal churchgoers might feel similarly regardless of their racial/ethnic background. Yet, the same study finds that perceiving depression as related to spiritual factors is not specific to a single denomination among Black pastors, suggesting that race does play a salient role. More comparative research is needed in this area. Second, the present study is exploratory in that we rely on a small sample of pastors and congregants in a major urban area in the U.S. with a robust network of mental health care providers. Future research should explore whether the patterns highlighted here might also be present in other contexts (e.g., communities with fewer mental health providers).

\section{Conclusions}

Our study helps fill an important gap in research on perceptions of mental health and mental health care in racial/ethnic minority communities. In particular, our comparative research design helps us understand not only differences across congregations based on racial/ethnic composition and denomination, but in introducing Latinos as a comparison case our work extends a line of research that has been primarily focused on Black Americans (Nguyen 2020). Further, our study helps identify differences between the experiences and perceptions of clergy members when compared to congregants. Ample research focuses solely on the perspectives of pastors (e.g., Avent et al. 2015; Bilkins et al. 2016; Okunrounmu et al. 2016) but with less focus on tensions that might exist between pastors and congregants when it comes to understanding the limits of pastor mental health care.

If pastors remain at the forefront of providing mental health care in many racial/ethnic minority communities - a conclusion supported by our results - then equipping pastors to better fill these roles is imperative for providing adequate care. While congregants in our study sought out pastors because of their perceived expertise, pastors lamented their own lack of training in pastoral care and the limits of their ability to care for mentally ill members. This tension only further magnifies the importance of calls for congregations to better connect with mental health care providers (Allen et al. 2010; Dempsey et al. 2016). News reports suggest that nearly 40 percent of pastors have considered leaving ministry since the start of COVID-19, in large part because of their own mental health needs as well as those of their congregation members (Shellnut 2021). Our research reveals how 
overwhelmed pastors who serve minority communities were before the pandemic. Now seems a ripe time to increase public health initiatives that target faith communities.

We conclude by providing some practical recommendations for clinicians. First, on a very broad level, our findings warrant bringing the perspectives of scholars of religion more into health policymaking, as partnerships between religious institutions and mental health care providers would greatly benefit from a better understanding of the institutional norms shaping the beliefs and practices of congregants in racial/ethnic minority congregations. Second, and relatedly, mental health professionals would be wise to consider how congregational norms around mental health might shape the potential scope of prospective interventions. For example, our work suggests that some Black churches might be entry points through which clinicians can start to reach out to the broader community while Latino churches like the one in our study may be more limited in their influence, given norms around mental health care were specific to the individual congregation. Next, our findings highlight the importance of identifying not only the reality but also the source of stigma surrounding mental health in different types of religious communities. We find that such stigma can be generalized to broader racial/ethnic communities or localized to particular congregations, each of which presents a unique set of challenges to address. Finally, our work highlights the limitations and potential demoralization that both pastors and congregants alike feel when trying to address mental health concerns. Indeed, a continued reliance on seeking care from individuals (i.e., pastors) who feel ill-equipped to provide such care only further underscores the urgency to support those who work on the frontlines of mental health care. Successful interventions, particularly around stigmatizing issues like mental health, must involve not only connecting with pastors to gain access to churches but also providing them with training and education to meet the needs of congregants and community members alike.

Author Contributions: Conceptualization, D.B. and P.J.P.; methodology, D.B. and P.J.P.; formal analysis, D.B.; investigation, D.B. and P.J.P.; resources, D.B.; data curation, D.B.; writing-original draft preparation, D.B. and P.J.P.; writing—review and editing, D.B. and P.J.P.; supervision, P.J.P.; project administration, D.B. All authors have read and agreed to the published version of the manuscript.

Funding: This work was funded by the Faculty Initiatives Fund at Rice University, Elaine Howard Ecklund PI.

Institutional Review Board Statement: The study was conducted according to the guidelines of the Declaration of Helskinki, and approved by the Institutional Review Board of Rice University (Study \#771951-1, approved 27 July 2015).

Informed Consent Statement: Informed consent was obtained from all subjects involved in the study.

Data Availability Statement: Data from the study are not publicly available due to privacy issues related to the anonymity of study respondents, in accord with the policies of the Institutional Review Board of Rice University.

Conflicts of Interest: The authors declare no conflict of interest.

\section{Notes}

AAB09, African American Woman, Nurse

AAB01, African American Woman, Manager of Operations

LUP02. Latino Man, Real Estate Agent

LUP03, Latina Woman, Special Education Teacher

LUP10, Latina Woman, Construction Worker

AAB09. African American Woman, Nurse

LUP08, Latino Man, Unemployed

Lat23, Latino Man, Pastor

AfAm11, African American Man, Pastor

AfAm11, African American Man, Pastor 
Lat23, Latino Man, Pastor

AfAm41, African American Man, Pastor

AfAm13, African American Woman, Pastor

AfAm46, African American Man, Pastor

AfAm41, African American Man, Pastor

LUP04, Latino Man, Benefits Coordinator/Co-Pastor

AAB05, African American Woman, Teacher

AAB01, African American Woman, Manager of Operations

AAB04, African American Man, Project Manager/Engineer

AAB06, African American Man, Tech Supervisor

LUP01, Latina Woman, Real Estate Agent

LUP06, Latina Woman, Human Resources Professional

LUP04, Latino Man, Benefits Coordinator/Co-Pastor

LUP Observation, 17 January 2016

LUP Observation, 18 October 2015

LUP07, Latina Woman, Physician

LUP05, Latina Woman, Retired

\section{References}

Association of American Medical Colleges. 2014. Diversity in the Physician Workforce: Facts \& Figures 2014. Available online: http:/ / aamcdiversityfactsandfigures.org/section-ii-current-status-of-us-physician-workforce/ (accessed on 8 November 2020).

Allen, Argie J., Maureen P. Davey, and Adam Davey. 2010. Being examples to the flock: The role of church leaders and African American families seeking mental health care services. Contemporary Family Therapy 32: 117-34. [CrossRef]

Avent, Janeé R., Craig S. Cashwell, and Shelly Brown-Jeffy. 2015. African American pastors on mental health, coping, and help seeking. Counseling and Values 60: 32-47. [CrossRef]

Barnes, Sandra L. 2004. Priestly and prophetic influences on Black church social services. Social Problems 51: 202-21. [CrossRef]

Baumann, Roger. 2016. Political engagement meets the prosperity gospel: African American Christian Zionism and Black church politics. Sociology of Religion 77: 359-85. [CrossRef]

Bilkins, Brianna, Argie Allen, Maureen P. Davey, and Adam Davey. 2016. Black church leaders' attitudes about mental health services: Role of racial discrimination. Contemporary Family Therapy 38: 184-97. [CrossRef]

Campbell, Rosalyn Denise, and Madison Rose Winchester. 2020. Let the church say ... : One congregation's views on how the Black Church can address mental health with Black Americans. Social Work E Christianity 47: 105-22.

Campbell, Rosalyn Denise, and Tenesha Littleton. 2018. Mental health counselling in the Black American church: Reflection and recommendations from counsellors serving in a counselling ministry. Mental Health, Religion $\mathcal{E}$ Culture 21: 336-52.

Caplan, Susan. 2019. Intersection of cultural and religious beliefs about mental health: Latinos in the faith-based setting. Hispanic Health Care International 17: 4-10. [CrossRef]

Carter, Nancy, Denise Bryant-Lukosius, Alba DiCenso, Jennifer Blythe, and Alan J. Neville. 2014. The use of triangulation in qualitative research. Oncology Nursing Forum 41: 545-47. [CrossRef]

Cavendish, James C. 2000. Church-based community activism: A comparison of Black and White Catholic congregations. Journal for the Scientific Study of Religion 39: 64-77. [CrossRef]

Chatters, Linda M., Robert Joseph Taylor, Amanda Toler Woodward, Amy S. B. Bohnert, Tina L. Peterson, and Brian E. Perron. 2017. Differences between African American and non-Hispanic Whites utilization of clergy for counseling with serious personal problems. Race and Social Problems 9: 139-49. [CrossRef]

Costanza, Alessandra, Marc Baertschi, Hélène Richard-Lepouriel, Kerstin Weber, Isabella Berardelli, Maurizio Pompili, and Alessandra Canuto. 2020a. Demoralization and its relationship with depression and hopelessness in suicidal patients attending an emergency department. International Journal of Environmental Research and Public Health 17: 2232. [CrossRef]

Costanza, Alessandra, Marc Baertschi, Hélène Richard-Lepouriel, Kerstin Weber, Isabella Berardelli, Maurizio Pompili, and Alessandra Canuto. 2020b. The presence and the search constructs of meaning in life in suicidal patients attending a psychiatric emergency department. Frontiers in Psychiatry 11: 327. [CrossRef] [PubMed]

Davenport, Alexandria D., and Heather F. McClintock. 2021. Religiosity and attitudes toward treatment for mental health in the Black Church. Race and Social Problems 13: 226-33. [CrossRef]

Dempsey, Keith, S. Kent Butler, and LaTrece Gaither. 2016. Black churches and mental health professionals: Can this collaboration work? Journal of Black Studies 47: 73-87. [CrossRef]

Espinosa, Gastón. 2014. Latino Pentecostals in America: Faith and Politics in Action. Cambridge: Harvard University Press.

Flyvbjerg, Bent. 2006. Five misunderstandings about case-study research. Qualitative Inquiry 12: 219-45. [CrossRef]

Frankham, Charlotte, Thomas Richardson, and Nick Maguire. 2020. Do locus of control, self-esteem, hope and shame mediate the relationship between financial hardship and mental health? Community Mental Health Journal 56: 404-15. [CrossRef] [PubMed] 
Galiatsatos, Panagis, and W. Daniel Hale. 2015. Promoting health and wellness in congregations through lay health educators: A case study of two congregations. Journal of Religion and Health 55: 288-95. [CrossRef] [PubMed]

Golash-Boza, Tanya, and William Darity Jr. 2008. Latino racial choices: The effects of skin colour and discrimination on Latinos' and Latinas' racial self-identifications. Ethnic and Racial Studies 31: 899-934. [CrossRef]

Gross, Tyra Toston, Chandra R. Story, Idethia Shevon Harvey, Marie Allsopp, and Melicia Whitt-Glover. 2018. "As a community, we need to be more health conscious": Perceptions on the health status of the Black Church and African American communities. Journal of Racial and Ethnic Health Disparities 5: 570-79. [CrossRef]

Hankerson, Sidney H., and Myrna M. Weissman. 2012. Church-based health programs for mental disorders among African Americans: A review. Psychiatric Services 63: 243-49. [CrossRef]

Hays, Krystal. 2015. Black churches' capacity to respond to the mental health needs of African Americans. Social Work E Christianity 42: 296-312.

Hays, Krystal, and Karen D. Lincoln. 2017. Mental health help-seeking profiles among African Americans: Exploring the influence of religion. Race and Social Problems 9: 127-38. [CrossRef]

Holt, Cheryl L., and Stephanie M. McClure. 2006. Perceptions of the religion-health Connection among African American church members. Qualitative Health Research 16: 268-81. [CrossRef] [PubMed]

Jurkowski, Janine M., Courtney Kurlanska, and Blanca M. Ramos. 2010. Latino women's spiritual beliefs related to health. American Journal of Health Promotion 25: 19-25. [CrossRef]

Kane, Michael N., and Margueritta Williams. 2000. Perceptions of South Florida Hispanic and Anglo Catholics: From Whom Would They Seek Help? Journal of Religion and Health 39: 107-21. [CrossRef]

Kennedy, Bernice Roberts, Christopher Clomus Mathis, and Angela K. Woods. 2007. African Americans and their distrust of the health care system: Healthcare for diverse populations. Journal of Cultural Diversity 14: 56-60. [PubMed]

Levin, Jeff. 2014. Faith-based initiatives in health promotion: History, challenges, and current partnerships. American Journal of Health Promotion 28: 139-41. [CrossRef] [PubMed]

Lincoln, C. Eric, and Lawrence H. Mamiya. 1990. The Black Church in the African American Experience. Durham: Duke University Press.

Mirowsky, John, and Catherine E. Ross. 2001. Age and the effect of economic hardship on depression. Journal of Health and Social Behavior 42: 132-50. [CrossRef] [PubMed]

Moreno, Oswaldo, and Esteban Cardemil. 2013. Religiosity and mental health services: An exploratory study of help seeking among Latinos. Journal of Latina/o Psychology 1: 53-67. [CrossRef]

National Center for Health Statistics. 2016. Health, United States, 2015: With Special Feature on Racial and Ethnic Health Disparities. May. Available online: https:/ / www.ncbi.nlm.nih.gov/ pubmed/27308685 (accessed on 23 November 2021).

National Science Foundation. 2013. Women, Minorities, and Persons with Disabilities in Science and Engineering. Available online: http://www.nsf.gov/statistics/wmpd/2013/digest/theme2_2.cfm (accessed on 23 November 2021).

Neighbors, Harold W., Marc A. Musick, and David R. Williams. 1998. The African American ministers as a source of help for serious personal crises: Bridge or barrier to mental health care? Health Education Behavior 25: 759-77. [CrossRef] [PubMed]

Nguyen, Ann W. 2020. Religion and mental health in racial and ethnic minority populations: A review of the literature. Innovation in Aging 4: 1-13. [CrossRef]

Okamoto, Dina, and G. Cristina Mora. 2014. Panethnicity. Annual Review of Sociology 40: 219-39. [CrossRef]

Okunrounmu, Elizabeth, Argie Allen-Wilson, Maureen Davey, and Adam Davey. 2016. Black church leaders' attitudes about seeking mental health services: Role of religiosity and spirituality. International Journal of Religion E Spirituality in Society 6: 45-55.

Ortega, Alexander N., Hector P. Rodriguez, and Arturo Vargas Bustamante. 2015. Policy dilemmas in Latino health care and implementation of the Affordable Care Act. Annual Review of Public Health 36: 525-44. [CrossRef] [PubMed]

Pattillo-McCoy, Mary. 1998. Church culture as a strategy of action in the Black community. American Sociological Review 63: 767-84. [CrossRef]

Payne, Jennifer Shepard. 2009. Variations in pastors perceptions of the etiology of depression by race and religious affiliation. Community Mental Health Journal 45: 355-56. [CrossRef]

Payne, Jennifer Shepard. 2017. "It's kind of a dichotomy": Thoughts related to calling and purpose from pastors working and counseling in urban resource-poor communities. Journal of Religion and Health 56: 1419-35. [CrossRef] [PubMed]

Pescosolido, Bernice A. 2013. The public stigma of mental illness: What do we think; What do we know; What can we prove? Journal of Health and Social Behavior 54: 1-21. [CrossRef]

Pew Research Center. 2015. America's Changing Religious Landscape. Available online: https://www.pewforum.org/2015/05/12 / americas-changing-religious-landscape/ (accessed on 20 March 2021).

Pickard, Joseph G., Sharon D. Johnson, Huei-Wern Shen, and Erin L. Mason. 2019. African American and European American clergy's counseling of older adults. Review of Religious Research 61: 221-34. [CrossRef]

Prickett, Pamela J. 2021. When the road is covered in nails: Making sense of madness in an urban mosque. Social Problems 68: 136-51. [CrossRef]

Sattin, Richard W., Lovoria B. Williams, James K. Dias, Jane Garvin, Lucy Marion, Thomas V. Joshua, Andrea Kriska, M. Kaye Kramer, and K. M. Venkat Narayan. 2016. Community trial of faith-based lifestyle intervention to prevent diabetes among African-Americans. Journal of Community Health 41: 87-96. [CrossRef] [PubMed] 
Schnittker, Jason, Jeremy Freese, and Brian Powell. 2000. Nature, nurture, neither, nor: Black-white differences in beliefs about the causes and appropriate treatment of mental illness. Social Forces 78: 1101-32. [CrossRef]

Shellnut, Kate. 2021. The Pastors Aren't All Right: 38\% Consider Leaving Ministry. Christianity Today, November 16. Available online: https:/ / www.christianitytoday.com/news/2021/november/pastor-burnout-pandemic-barna-consider-leaving-ministry. html(accessed on 19 November 2021).

Sternthal, Michelle J., David R. Williams, Marc A. Musick, and Anna C. Buck. 2012. Religious practices, beliefs, and mental health: Variations across ethnicity. Ethnicity $\mathcal{E}$ Health 17: 171-85.

Tavory, Iddo, and Stefan Timmermans. 2014. Abductive Analysis: Theorizing Qualitative Research. Chicago: University of Chicago Press.

Tinsley, Cleve, Pamela J. Prickett, and Elaine Howard Ecklund. 2018. Black Protestant views of science. Du Bois Review 15: 533-46. [CrossRef]

Villatoro, Alice P., Eduardo S. Morales, and Vickie M. Mays. 2014. Family culture in mental health help-seeking and utilization in a nationally representative sample of Latinos in the United States: The NLAAS. American Journal of Orthopsychiatry 84: 353-63. [CrossRef] [PubMed]

Villatoro, Alice P., Vickie M. Mays, Ninez A. Ponce, and Carol S. Aneshensel. 2018. Perceived need for mental health Care: The intersection of race, ethnicity, gender, and socioeconomic status. Society E Mental Health 8: 1-24.

Wong, Eunice C., Brad R. Fulton, and Kathryn P. Derose. 2018. Prevalence and predictors of mental health programming among U.S. religious congregations. Psychiatric Services 69: 154-60. [CrossRef] 